\title{
Risk Factors Associated with the Abuse of Video Games in Adolescents
}

\author{
Ricardo A. Tejeiro ${ }^{1}$, Jorge L. Gómez-Vallecillo ${ }^{1}$, Manuel Pelegrina ${ }^{2}$, \\ Agustín Wallace $^{2}$, Enrique Emberley ${ }^{3}$ \\ ${ }^{1}$ Departamento de Psicología, Facultad de Ciencias de la Educación, Universidad de Cádiz, \\ Campus Río San Pedro, Cádiz, Spain \\ ${ }^{2}$ Departamento de Metodología, Facultad de Psicología, Universidad de Málaga, Málaga, Spain \\ ${ }^{3}$ Centro de Profesorado del Campo de Gibraltar, La Línea de la Concepción, Spain \\ Email: \{ricardo.tejeiro, jorge.gomez\}@uca.es, \{pelegrina, awallace\}@uma.es, emberley@cop.es
}

Received January $4^{\text {th }}$, 2012; revised February $10^{\text {th }}$, 2012; accepted March $16^{\text {th }}, 2012$

\begin{abstract}
Several studies have revealed the existence of a maladaptive pattern of video game use whose symptoms are quite similar to those of the disorder referred to as "abuse" in the DSM-IV-TR (APA, 2000). The aim of this paper is to examine the psychosocial characteristics of the adolescent video game abusers and to compare them with the risk factors that the literature associates with substance dependence. For this purpose, two groups ("problem" and "social” players) were formed with 236 Spanish adolescents aged between 12 and 17 years, by means of the Problem Video Game Playing questionnaire (PVP; Tejeiro \& Bersabe, 2002), and their psychosocial characteristics were then analyzed by means of a wide battery of tests. Only $37.3 \%$ of the problem players showed a psychosocial pattern similar to the risk factors for dependence; an integral model of maladaptive behavior is discussed as explanation for these persons' video game abuse. The other $69.6 \%$ of "problem players" only differed from the "social players" in their overuse of video games (but not in other psychosocial factors); the social learning approach is suggested for these adolescents' behavior.
\end{abstract}

Keywords: Video Games; Adolescence; Dependence; Abuse; Risk Factors

\section{Introduction}

Over the last 30 years, addiction has been one of the problems most commonly associated with the use of video games (Tejeiro, Pelegrina, \& Gómez-Vallecillo, 2009). As with the presumed behavioral addictions to Internet (Ferraro, Caci, D’Amico, \& Di Blasi, 2007), cell phone (Beranuy, Chamarro, Graner, \& Carbonell, 2009), sex (Goodman, 1989) and others, the adaptation of the diagnostic criteria for substance dependence or pathological gambling from the American Psychiatric Association's Diagnostic and Statistical Manual of Mental Disorders (DSM) has been the methodological choice of a majority of diagnostic or screening studies on video game "addiction". Results range from 6 to 19 percent of apparently "addicted" video game players, as shown in Table 1.

One of the scales developed from this perspective is the PVP (Problem Video Game Playing Questionnaire; Tejeiro \& Bersabe, 2002). Its 9 items are based on the DSM-IV (APA, 1994) criteria for substance dependence and for pathological gambling, as well as the literature on addictions. Psychometric analyses show that the PVP is one-dimensional and has acceptable internal consistency (Cronbach's alpha) at .69. The pattern of associations between the scale scores and alternative measures of problem play supports its construct validity (higher total scores in the scale were associated with higher frequency of play, mean and longest times per session, self and parents perception of playing to excess, and scores in the Severity of Dependence Scale).

However, while it is true that the PVP and other DSM adaptations make it possible to detect and to assess the presence of an apparently addictive disorder, it remains unclear if this disorder can be referred to as an "addiction". The PVP authors presented their instrument as a quantitative measure, not as a tool for the diagnosis of addiction, and different studies in the

Table 1.

“Addiction" to video games: prevalence studies.

\begin{tabular}{ccc}
\hline Study & Country & Percentage of "addicted” \\
\hline Fisher (1994, 1995) & UK & $6 \%$ \\
Griffiths \& Dancaster (1995) & UK & $8 \%$ \\
Phillis, Rolls, Rouse, & UK & $7.5 \%$ \\
$\begin{array}{c}\text { \& Griffiths (1995) } \\
\text { Haugue \& Gentile } \\
\text { (2003) }\end{array}$ & USA & $15 \%$ \\
Arab et al. (2006) & Chile & $10 \%-15 \%$ \\
Rau, Peng, \& Yang (2006) & China & $19 \%$ \\
Grusser, Thalemann, & Germany & $11.9 \%$ \\
\& Griffiths (2007) & Taiwan & $7.5 \%$ \\
Ko et al. (2007) & France & $8 \%$ \\
Moussa (2008) & USA & $8.5 \%$ \\
Gentile (2009) & China & $10.3 \%$ \\
Peng \& Li (2009) & Australia & $8 \%$ \\
Porter, Starcevic, & Singapore & $9.9 \%$ \\
Berle, \& Fenech (2010) & & \\
Gentile et al. (2011) & &
\end{tabular}


United States of America (Lyles, 2007; Langley, 2010; Elliott, Golub, Ream, \& Dunlap, 2011; Ream, Elliott, \& Dunlap, 2011a, 2011b; Tolchinsky \& Jefferson, 2011), France (Bioulac, Arfi, \& Bouvard, 2008, 2010), United Kingdom (Collins, Freeman, \& Chamarro-Premuzic, 2012), Canada (Adlaf, Paglia-Boak, Beitchman, \& Wolfe, 2008; Parker et al., 2008; Taylor, 2008; Lafrenière, Vallerand, Donahue, \& Lavigne, 2009), Iceland (Hróarsson, 2004; Einarsdóttir, 2008; Skarphédinsson, Pálsdóttir, \& Ólason, 2008), China (De-Lin Sun et al., 2008), Australia (Loton, 2007), Brazil (Icassati-Suzuki, Vieira, Araujo, \& Magallaes, 2009), Thailand (Supaket, Munsawaengsub, Nanthamongkolchai, \& Apinuntavetch, 2008) and Peru (Vallejos \& Capa, 2010) have followed this suggestion in using the PVP as a quantitative approach. Contrariwise, Arab et al. (2006, 2007) in Chile used the instrument to diagnose "video game addiction" when respondents answered affirmatively 2 or more items.

Tejeiro (2002) suggested that the pattern of problems associated with high PVP scores can be best referred to as "abuse", since it is quite similar to the DSM-IV-TR (APA, 2000) criteria for substance abuse: a maladaptive pattern (of use) leading to clinically significant impairment or distress as manifested by a failure to fulfill major role obligations at school or home, or continued use despite having persistent or recurrent social or interpersonal problems caused or exacerbated by the behavior (arguments, physical fights). Similarly, Sánchez-Carbonell, Beranuy, Castellana, Chamarro, \& Oberst (2008) concluded that the presumed mobile phone addiction should be better conceptualized as an example of abuse.

Another problem with this approach is that all the studies that have used DSM based instruments have considered the "addicted" video game players as a homogeneous group, but in no case this homogeneity has been tested. For example, Haughe and Gentile stated that "the addicted group revealed more reports of involvement in physical fights in the last year, more arguments with friends and teachers, higher hostile attribution scores, and lower grades" (Haughe \& Gentile, 2003), but they didn't specify if all the "addicted" did equally share this problem profile.

The current study utilizes one of these instruments, the PVP, to analyze the psychosocial characteristics of those adolescents who are video games abusers. Our hypothesis is that these risk factors are similar to those of substance abusers. For this purpose, an integral approach to the addictions will be assumed in which this condition is associated with numerous risk and protection factors, both individual and social (Calafat, Armengual, Farres, Mejias, \& Borras, 1992).

\section{Method}

\section{Participants}

Seven hundred and thirty seven secondary school students participated in the study. Students were recruited from ten urban public schools in the Spanish cities of La Linea, Algeciras and Puerto Real. The mean age of respondents was 14 years $(\mathrm{SD}=1.12)$. Forty-eight percent of respondents were female. Participants were treated in accordance with the "Ethical Principles of Psychologists and Code of Conduct” (American Psychological Association, 1992).

\section{Materials}

Data were collected by means of a questionnaire designed for the present study and several self-report instruments. Our questionnaire was divided into two parts. The first part was to be fulfilled by the student and contained 12 questions regarding his or her video game beliefs and behaviors; it also included a classical sociometric procedure to measure popularity and status in the class-group. The second part, to be fulfilled by his or her teacher, included 6 questions regarding the students' behavior and achievement. The other instruments were the PVP (Tejeiro \& Bersabe, 2002), Eysenck Personality QuestionnaireJunior (EPQ-J; Eysenck \& Eysenck, 1975), third self-administered version of the Socialization Battery (Batería de Socialización BAS-3; Silva \& Martorell, 1984), Self-concept Questionnaire, form A (Cuestionario de Autoconcepto AFA; Musitu, García \& Gutiérrez, 1991), Impulsiveness, Venturesomeness and Empathy Scale (IVE-J; Eysenck, Easting, \& Pearson, 1984), A-D Anti-social Illegal Behaviors Questionnaire (Cuestionario A-D de Conductas Anti-sociales-Ilegales; Seisdedos, 1988), General Intelligence Test Domino series Form 2 (Test General de Inteligencia TIG-2; TEA, 1990) and Situation-1 Spatialperceptive Test (Test Espacial-Perceptivo Situation-1; Seisdedos, 1990). Analyses were conducted using the SPSS version 15.0 (SPSS, Chicago, IL, USA).

\section{Procedure}

Interested teachers volunteered their classrooms for inclusion in the study and helped obtaining parental consent, with consent levels greater than 95\% for all classrooms. Each participant then completed the nine PVP items in a form administered by the researchers during regular classroom hours. Since our purpose was to compare "addicted" versus "non addicted" players, all the 118 participants who scored 4 or more in the PVP (16.01\% of respondents) were further considered as "problem players".

This cut-off point of 4 follows the suggestions of Griffiths (1991) and Fisher (1994, 1995), but it must be noted that in posterior analysis it was found that a variation to 5 or 3 would not significantly affect the results. Their PVP scores ranged from 4 to $7(\mathrm{M}=5.40$; $\mathrm{SD}=.92)$. A second group of 118 "social players" was then formed, matched in gender and age with the previous group, among those who had played video games during the previous year but scored less than 4 in the PVP. "Problem" and "social players" continued in the study and completed the rest of the aforementioned questionnaires.

\section{Results}

A cluster analysis was performed on the data from EPQ-J, BAS-3, AFA, A-D, TIG-2, Situation-1 and IVE-J, which identified two groups of 44 and 192 persons. All the players in the first group were problem players, whereas the second group included problem and social players. Three groups should therefore be distinguished: $\mathrm{C} 1$, formed by the 44 participants from the first original cluster, this is, $37.3 \%$ of the problem players; C2, formed by the 74 problem players not included in $\mathrm{C} 1$; and C3, formed by the 118 social players.

The male-female ratio is higher in C1 $(6: 1)$ than in C2 (1.46:1) and C3 (2.07:1), but differences are not significant $\left(\chi^{2}(2)=3.08 ; p=.215\right)$. The years of experience with the video games in $\mathrm{C} 1(\mathrm{M}=8.00, \mathrm{SD}=1.30)$ are similar to those in $\mathrm{C} 2$ $(M=7.91 ; S D=1.15)$ and both higher than in $\mathrm{C} 3(\mathrm{M}=4.70$; $\mathrm{SD}=2.52)(F=5.91 ; p=.004)$. Differences between groups 
were evaluated by one-factor ANOVAS with post hoc Tamhane's T2, Pearson's chi-square and Student's t tests. C1 and C3 members were significantly different in most of the variables, whereas C2 were similar to $\mathrm{C} 1$ in all the variables directly related to the use of video games, but similar to C3 in the other variables. Results are resumed in Table 2.

C1 members are different to the others in the following variables: they score higher in introversion, hardness and tendency to anti-social and illegal behaviors, and they score lower in sincerity, empathy, consideration for the others and self-concept. Their teachers tend to consider them as conflictive and maladapted. These players think that their video game play is a normal behavior, but they believe that video games may lead to addiction, displacement of educational and social activities, aggressiveness and poor school performance. They perceive a low parental knowledge and control of their use of video games, as well as low control of their general behavior. Poor communication and affective relationships are also found in these

Table 2.

Mean scores and statistical significance.

\begin{tabular}{cccccc}
\hline & Cluster 1 & Cluster 2 & Cluster 3 & $F$ & $p$ \\
\hline PVP & 5.29 & 5.16 & $\mathbf{1 . 2 2}$ & 235.2 & .000 \\
\hline EPQ-J: & & & & & \\
Neuroticism & $\mathbf{1 6 . 0 7}$ & 13.66 & 13.07 & 4.91 & .009 \\
Extraversion & $\mathbf{8 . 9 3}$ & 13.31 & 12.72 & 28.75 & .000 \\
Hardmess & $\mathbf{3 . 6 4}$ & 1.66 & 1.83 & 20.46 & .000 \\
Sincerity & $\mathbf{5 . 9 3}$ & 9.78 & 9.59 & 26.52 & .000 \\
Antisocial behavior & $\mathbf{2 2 . 7 9}$ & 17.34 & 17.24 & 13.45 & .000 \\
BAS-3: & & & & & \\
Consideration & $\mathbf{1 0 . 0 7}$ & 12.03 & 12.04 & 22.26 & .000 \\
Self-control & $\mathbf{6 . 5 7}$ & 8.03 & 8.67 & 7.94 & .001 \\
Retreat & $\mathbf{4 . 5 7}$ & 2.56 & 2.48 & 9.64 & .000 \\
Social anxiety & 4.43 & 3.66 & 4.13 & 1.47 & .236 \\
Leadership & $\mathbf{8 . 4 3}$ & 7.25 & 7.07 & 4.22 & .018 \\
Sincerity & 5.86 & 5.81 & 5.70 & .13 & .880 \\
AFA: & & & & & \\
Academic self-c. & $\mathbf{1 7 . 8 6}$ & 22.91 & 23.02 & 79.83 & .000 \\
Social self-concept & $\mathbf{5 . 3 6}$ & 8.50 & 8.41 & 25.48 & .000 \\
Emotional self-c. & $\mathbf{1 4 . 6 4}$ & 20.38 & 20.52 & 63.89 & .000 \\
Family self-concept & $\mathbf{6 . 3 6}$ & 9.75 & 9.83 & 37.67 & .000 \\
Total self-concept & $\mathbf{4 4 . 2 1}$ & 61.53 & 61.83 & 79.13 & .000 \\
IVE-J: & & & & & \\
Impulsiveness & 13.29 & 12.88 & 12.46 & 1.09 & .340 \\
Desire for adventure & $\mathbf{1 6 . 5 0}$ & 18.69 & 17.91 & 5.73 & .005 \\
Empathy & $\mathbf{1 3 . 7 1}$ & 16.88 & 16.63 & 22.37 & .000 \\
A-D: & & & & & \\
Antisocial behavior & $\mathbf{1 2 . 2 9}$ & 8.75 & 8.35 & 24.28 & .000 \\
Criminal behavior & $\mathbf{3 . 4 3}$ & .94 & .93 & 46.81 & .000 \\
\hline & 24.14 & 23.38 & 23.46 & .42 & .660 \\
TIG-2 & 38.29 & 36.94 & 37.22 & .38 & .685 \\
\hline & & & & &
\end{tabular}

families. C1 members report low shared play with their parents, few conversations with them about this topic, lower family satisfaction, less positive family context and less perceived proximity to their parents. They also report higher gambling, tobacco and alcohol use among their friends. Finally, these players show higher absenteeism, lower satisfaction with their school and teachers, worse relationships with their teachers, and lower satisfaction with their city and neighborhood.

C1 and C2 members, but not C3 members, share the following characteristics: they play video games frequently ("daily" or "almost daily") and in long sessions (1.5 to 2 hours). They tend to have friends who also play video games, they like to talk to them about this activity and they prefer and practice shared play. TV console and computer are their preferred systems, while sports, platforms and adventures are their favorite types of play. C1 and C2 members own more games and more game systems, and they tend to play at home or in the homes of friends.

No inter-cluster differences were found in the following variables: intelligence, perceptive and spatial skills, entertainment as first reason for playing, family structure and composition, socio-economic status, frequency and satisfaction with peer relations, and school grades.

\section{Discussion}

All those who scored 4 or more in the PVP seem to present a problem of video game abuse, although only one third of them (included in C1) revealed a pattern of psychosocial characteristics similar to the pattern of risk factors consistently associated with addictions in the literature. The other problem players simply have a high involvement with video games and show a number of problem behaviors associated with this activity. Therefore, our hypothesis was only confirmed for C1 members.

The integrated models of maladaptive behavior can account for the abuse of video games in C1. Research has consistently demonstrated the importance of the family with regards to the development of behavioral problems in children and adolescents (Dekovic, Janssens, \& Van As, 2003). Characteristics such as conflict, lack of warmth and communication, and negligent discipline have been identified as leading factors in adolescents developing behavior problems that include maladaptation (less satisfaction, poor personal well-being and worse relationships with the figures of authority), low self-esteem and the use of drugs as alternative gratification source (e.g., Brook, Brook, Gordon, Whiteman, \& Cohen, 1990). These children tend to seek peer support and guide (López, 1986). If their personality is as found in C1 (low consideration, low empathy, high neuroticism, high hardness, tendency to anti-social and illegal behaviors), their odds of joining maladapted groups increase. The model offered by these groups includes substance abuse, gambling and anti-social behaviors. Some characteristics of the video games are particularly relevant to this pattern of relationships. Video games represent a world that is seldom or never visited by adults. Parents hardly know about the games or control their children's use of games (Colwell \& Pain, 2000). Video games are also a challenging experience (Lepper \& Malone, 1987), a chance for these adolescents to test their skills and thus to perceive a feeling of control and competence that helps overcoming their low self-esteem. Video games help the teenagers to identify themselves with the group and to find a place in its hierarchy (Suess et al., 1998). Finally, they provide a chance to put into practice the adolescent's fantasies of de- 
struction and aggression with a high degree of realism but without possibility of harm (Turkle, 1984). Therefore, maladapted adolescents, as compared with other groups, will tend to play more with the video games and to show higher levels of problem behaviors (absenteeism, lies, fights, etc.) not only associated with the games but also with other realms of their lives.

As for C2 members, the social learning approach seems to provide the best explanation for their abuse of video games. Higher involvement in this activity (and higher exposure to its effects) can be seen as a consequence of the vicinity of peers who play. C2 members were found to own more video games and more game systems, as compared with the "non abuse" group; it is difficult to state whether higher ownership is the cause or a consequence of a higher involvement, but probably the effects are bidirectional. Finally, higher involvement is probably associated with lower parental control.

It can be concluded that adolescents tend to practice pleasant activities without moderation, and that they find higher attractiveness in the video games than in most alternative activities. A poor parent involvement in video game habits is expected to facilitate the onset of problems, especially among problem adolescents. Their condition can then be considered a form of abuse.

A number of caveats need to be noted regarding the present study. First, it included a small sample of a specific age group from a determined geographical area. This study is also based on the PVP and therefore might be affected by any mistake in this instrument's design or validation. Finally, the strict observance of research ethics excluded the analysis of some potentially relevant variables, such as aggressive behaviors in parents.

\section{REFERENCES}

Adlaf, E. M., Paglia-Boak, A, Beitchman, J. H., \& Wolfe, D. (2008). The mental health and well-being of Ontario students, 1991-2007: Detailed OSDUHS findings. CAMH Research Document Series, No. 22. Toronto: Centre for Addiction and Mental Health.

American Psychiatric Association (1994). Diagnostic and statistical manual of mental disorders (4th ed.). Washington, DC: Author.

American Psychiatric Association (2000). Diagnostic and statistical manual of mental disorders (4th ed.). Washington, DC: Author.

American Psychological Association (1992). Ethical principles of psychologists and code of conduct. American Psychologist, 47, 15971611. doi:10.1037/0003-066X.47.12.1597

Arab, E., Sommer, K., Herskovic, V., Sommer, S., Sandoval, C., \& Poblete, C. (2007). Evaluación del uso de video juego en escolares de la región metropolitana. Revista Chilena de Psiquiatría y Neurología en la Infancia y la Adolescencia, 18, 7-11.

Arab, E., Sommer, K., Herskovic, V., Sommer, S., Sandoval, C., \& Poblete, C. (2006). Evaluación del uso de video juego en escolares de la región metropolitana. Comunicación presentada en las XXIII Jornadas de Investigación del Hospital Luis Calvo Mackenna. Santiago de Chile.

Beranuy, M., Chamarro, A., Graner, C., \& Carbonell, X. (2009). Validación de dos escalas breves para evaluar la adicción a Internet y el abuso de móvil. Psicothema, 21, 480-488.

Bioulac, S., Arfi, L., \& Bouvard, M. P. (2008). Attention deficit/hyperactivity disorder and video games: A comparative study of hyperactive and control children. European Psychiatry, 23, 134-141. doi:10.1016/j.eurpsy.2007.11.002

Bioulac, S., Arfi, L., Michel, G., \& Bouvard, M. P. (2010). Intérêt de l'utilisation du questionnaire des problèmes associés aux jeux vidéo de Tejeiro (Problem Videogame Playing : PVP). Étude exploratoire chez des enfants présentant un TDA/H. Annales Médico-Psychologiques, 168, 632-635. doi:10.1016/j.amp.2010.07.001

Brook, J. S., Brook, D. W., Gordon, A. S., Whiteman, M., \& Cohen, P. (1990). The psychosocial etiology of adolescent drug use: A family interactional approach. Genetic, Social and General Psychology Monographs, 116, 111-267.

Calafat, A., Armengual, M., Farrés, C., Mejías, G., \& Borrás, M. (1992). Tú decides, programa de educación sobre drogas (3rd ed.). Mallorca: Secció de Promoció de la Salut. Servei d'Acció Social i Sanitat.

Collins, E., Freeman, J., \& Chamarro-Premuzic, T. (2012). Personality traits associated with problematic and non-problematic massively multiplayer online role playing game use. Personality and Individual Differences, 52, 133-138. doi:10.1016/j.paid.2011.09.015

Colwell, J., \& Pain, J. (2000) Negative correlates of computer game play in adolescents. British Journal of Psychology, 91, 295-310. doi:10.1348/000712600161844

Dekovic, J., Janssens, J. M., \& Van As, N. M. (2003). Family predictors of anti-social behavior in adolescence. Family Process, 42, 223-235. doi:10.1111/j.1545-5300.2003.42203.x

De-Lin, S., Ning, M., Min, B., Chen, X.-C., \& Zhang, D.-R. (2008). Computer games: A double-edged sword? Cyberpsychology \& Behavior, 11.

De Waal, B. (1995). Motivation for video game play: A study of social, cultural and physiological factors. M.A. Thesis, Burnaby: Simon Fraser University.

Einarsdóttir, H. (2008). Prevalencia del uso de videojuegos y de los problemas con los videojuegos entre los jóvenes islandeses: Examen de los factores de riesgo potenciales para el uso problemático de videojuegos. Tesis de Licenciatura, Reykjavík: Universidad de Islandia.

Elliott, L., Golub, A., Ream, G., \& Dunlap, E. (2011). Video game genre as a predictor of problem use. Cyberpsychology, Behavior, and Social Networking, 15, 127-128.

Eysenck, H. J., \& Eysenck, S. B. G. (1975). Manual of the eysenck personality questionnaire. London: Hodder and Stoughton.

Eysenck, S. B. G., Easting, G., \& Pearson, P. R. (1984). Age norms for impulsiveness, venturesomeness and empathy in children. Personality and Individual Differences, 5, 315-321. doi:10.1016/0191-8869(84)90070-9

Ferraro, G., Caci, B., D’Amico, A., \& Di Blasi, M. (2007). Internet addiction disorder: An Italian study. Cyberpsychology \& Behavior, 10, 170-175. doi:10.1089/cpb.2006.9972

Fisher, S. E. (1994). Identifying video game addiction in children and adolescents. Addictive Behaviors, 19, 545-553. doi:10.1016/0306-4603(94)90010-8

Fisher, S. E. (1995). The amusement arcade as a social space for adolescents: An empirical study. Journal of Adolescence, 18, 71-86. doi:10.1006/jado.1995.1006

Gentile, D. (2009). Pathological video-game use among youth ages 8 to 18. Psychological Science, 20, 594-602. doi:10.1111/j.1467-9280.2009.02340.x

Gentile, D. A., Choo, H., Liau, A., Sim, T., Li, D., Fung, D., \& Khoo, A. (2011). Pathological video game use among youths: A two-year longitudinal study. Pediatrics, 127, 319-329. doi:10.1542/peds.2010-1353

Goodman A. (1989). Addiction defined: Diagnostic criteria for addictive disorder. American Journal of Preventive Psychiatry and Neurology, 2, 12-15.

Griffiths, M. D., \& Dancaster, I. (1995). The effect of Type A personality on physiological arousal while playing computer games. Addictive Behaviors, 20, 543-548. doi:10.1016/0306-4603(95)00001-S

Griffiths, M. D. (1991). Amusement machine playing in childhood and adolescence: A comparative analysis of video games and fruit machines. Journal of Adolescence, 14, 53-73. doi:10.1016/0140-1971(91)90045-S

Grusser, S. M., Thalemann, R., \& Griffiths, M. D. (2007). Excessive computer game playing: Evidence for addiction and agresión? Cyberpsychology \& Behavior, 10, 290-292.

Hauge, M. R., \& Gentile, D. A. (2003). Video game addiction among adolescents: Associations with academic performance and aggression. 2003 Society for Research in Child Development Biennial Confer- 
ence, Tampa, 24-27 April 2003.

Hróarsson, H. (2004). Examen del potencial uso problemático de videojuegos entre los participantes en el terremoto 2004. Tesis de Licenciatura, Reykjavík: Universidad de Islandia.

Icassati, S. F. T., Vieira, M. M., Araujo, S. M. T., \& Magalhães Tavares de Oliveira, M. P. (2009). O uso de videogames, jogos de computador e internet por uma amostra de universitários da Universidade de São Paulo. Jornal Brasileiro de Psiquiatria, 58, 162-168.

Ko, C. H., Yen, J. Y., Yen, C. F., Lin, H. C., \& Yang, M. J. (2007). Factors predictive for incidence and remission of Internet addiction in young adolescents: A prospective study. Cyberpsychology \& Behavior, 10, 545-551. doi:10.1089/cpb.2007.9992

Lafrenière, M. A. K., Vallerand, R. J., Donahue, E. G., \& Lavigne, G. L. (2009). The role of passion on the costs and benefits of online video gaming. Cyberpsychology \& Behavior, 12.

Langley, A. (2010). Correlates of video game addiction. Master of Science (Psychology), Denton: University of North Texas.

Lepper, M. R., \& Malone, T. W. (1987). Intrinsic motivation and instructional effective-ness in computer-based education. In R. E. Snow, \& M. J. Farr (Eds.), Aptitude, learning and instruction (Vol. 3, pp. 255-285). Hillsdale, NJ: Erlbaum.

López, F. (1986). El desarrollo de los vínculos afectivos. Madrid: Ministerio de Educación y Ciencia.

Loton, D. (2007). Problem video game playing, self esteem and social skills: An online study. Melbourne: Tesina de Licenciatura en Psicología, Victoria University.

Lyles, H. (2007). Video game addiction: Truth or fiction. 18th Annual Research Symposium, Stillwater: Oklahoma State University.

Moussa, N. (2008). Addition aux jeux vidéo: Étude en ligne d’une population de joeurs passionnés. Doctoral thesis, Paris: Universite de Paris Descartes.

Musitu, G., García, F., \& Gutiérrez, M. (1991). Autoconcepto forma A. Madrid: TEA

Parker, J. D. A., Taylor, R. N., Eastabrook, J. M., Schell, S. L., \& Wood, L. M. (2008). Problem gambling in adolescence: Relationships with internet misuse, gaming abuse and emotional intelligence. Personality and Individual Differences, 45, 174-180. doi:10.1016/j.paid.2008.03.018

Peng, L. H., \& Li, X. (2009). A surrey of Chinese collage students addicted to video games. China Education Innovation Herald, 28, 111112.

Phillips, C. A., Rolls, S., Rouse, A., \& Griffiths, M. D. (1995) Home video game playing in schoolchildren: A study of incidence and patterns of play. Journal of Adolescence, 18, 687-691. doi:10.1006/jado.1995.1049

Porter, G., Starcevic, V., Berle, D., \& Fenech, P. (2010). Recognizing problem video game use. Australia and New Zealand Journal of Psychiatry, 44, 120-128. doi:10.3109/00048670903279812

Rau, P. L., Peng, S. Y., \& Tang, C. C. (2006). Time distortion for expert and novice online game players. Cyberpsychology \& Behavior, 9, 396-403. doi:10.1089/cpb.2006.9.396
Ream, G. L., Elliott, L. C., \& Dunlap, E. (2011a). Patterns of and motivations for concurrent use of video games and substances. International Journal of Environmental Research and Public Health, 8, 3999-4012. doi:10.3390/ijerph8103999

Ream, G. L., Elliott, L. C., \& Dunlap, E. (2011b). Playing video games while using or feeling the effects of substances: Associations with substance use problems. International Journal of Environmental Research and Public Health, 8, 3979-3998. doi:10.3390/ijerph8103979

Sánchez-Carbonell, X., Beranuy, M., Castellana, M., Chamarro, A., \& Oberst, U. (2008). La adicción a Internet y al móvil, moda o trastorno? Adicciones, 20, 149-160.

Seisdedos, N. (1988). Cuestionario A-D, conductas anti-sociales-delictivas. Manual. Madrid: TEA.

Seisdedos, N. (1990). Situación-1, test espacio-perceptivo. Manual. Madrid: TEA

Silva, F., \& Martorell, M. C. (1984). BAS, batería de socialización. Madrid: TEA

Skarphédinsson, G. A., Pálsdóttir, S. E., \& Ólason, D. P. (2008). Evaluación de problemas con los videojuegos: Propiedades psicométricas y relación con tipo de juego. Sálfraediritid-Tímarit Sálfraedingafélags Íslands, 13, 47-64.

Suess, D., Suoninen, A., Garitanonandia, C., Juaristi, P., Koikkalainen, R., \& Oleaga, J. A. (1998). Media use and the relationships of children and teenagers with their peer groups. A study of Finnish, Spanish and Swiss Cases. European Journal of Communication, 13, 521538. doi:10.1177/0267323198013004005

Supaket, P., Munsawaengsub, Ch., Nanthamongkolchai, S., \& Apinuntavetch, S. (2008). Factors affecting computer game addiction and mental health of male adolescents in Mueang District, Si Sa Ket Province. Journal of Public Health, 38, 317-330.

Taylor, R. N. (2008). Adolescent problem gambling: Relationship with affect regulation, internet addiction and problematic video game playing. Tesis de Master, Ontario: Trent University.

TEA Ediciones, S. A. (1990). TIG-2. Tests de inteligencia general (Serie dominós) Forma 2. Madrid: TEA.

Tejeiro, R., \& Bersabé, R. M. (2002). Measuring problem video game playing in adolescents. Addiction, 97, 1601-1606. doi:10.1046/j.1360-0443.2002.00218.x

Tejeiro, R., Pelegrina, M., \& Gómez Vallecillo, J. L. (2009). Efectos psicosociales de los videojuegos. Comunicación, 7, 235-250.

Tolchinsky, A., \& Jefferson, S. D. (2011). Problematic video game play in a college sample and its relationship to time management skills and attention-deficit/hyperactivity disorder symptomology. Cyberpsychology, Behavior, and Social Networking, 14, 489-496. doi:10.1089/cyber.2010.0315

Turkle, S. (1984). The second self: Computers and the human spirit. London: Granada.

Vallejos, M., \& Capa, W. (2010). Videojuegos: Adicción y factores predictors. Avances en Psicología, 18, 103-110. 